\title{
GEOCHEMISTRY AND GEOCHRONOLOGY OF PALEOPROTEROZOIC GNEISSIC ROCKS OF THE PARAÍBA DO SUL COMPLEX (QUIRING UNIT), BARRA MANSA REGION, RIO DE JANEIRO, BRAZIL
}

\author{
CLAUDIA SAYAO VALLADARES*; MONICA HEILBRON*; MÁRIO CESAR HEREDIA DE FIGUEIREDO*** (IN \\ MEMORIAN) \& WILSON TEIXEIRA**
}

\begin{abstract}
RESUMO GEOQUÏMICA E GEOCRONOLOGIA DE ROCHAS GNAÍSSICAS PALEOPROTEROZÓICAS DO COMPLEXO PARAIIBA DO SUL (UNIDADE QUIRINO), REGIÃO DE BARRA MANSA, RIO DE JANEIRO, BRASIL Este trabalho apresenta e discute novos dados de geoquímica das rochas ortognaíssicas do Complexo Paraíba do Sul (CPS), aflorantes ao NW do Estado do Rio de Janeiro, denominadas de Unidade Quirino. São também discutidos os dados de geocronologia U-Pb, da referida Unidade (obtidos no GEOTOP-UQAM, Canadá), apresentados em Valladares (1996) e em Machado et al. (1996). A Unidade Quirino, juntamente com as unidades metassedimentares do CPS e os granitóides intrusivos, estes últimos gerados durante a Orogênese Brasiliana, compreendem o Domínio Tectônico Paraíba do Sul (DTPS) ou Domínio Tectônico Superior, no âmbito do segmento central da Faixa Ribeira. A Unidade Quirino ocorre como extensos corpos de gnaisses homogêneos em fácies anfibolito alto, com hornblenda e/ou biotita, perfazendo ca. de $50 \%$ da área mapeada e $70 \%$ em superficie do DTPS. Foi gerada a $2185 \pm 3 \mathrm{Ma}$ e $2169 \pm 3 \mathrm{Ma}$ (dados U-Pb em zircão), e está temporalmente relacionada a evolução do Ciclo Transamazônico. Idades mínimas de $2846 \mathrm{Ma}$ e $2981 \mathrm{Ma}$ (dados U-Pb em zircão), revelam a pré-existência de crosta arqueana como fonte de $\mathrm{Pb}$ para parte dos gnaisses investigados. As investigacões geoquímicas realizadas nos ortognaisses da Unidade Quirino revelaram a existência de duas suítes calcio-alcalinas: uma de médio- a alto-K e outra de alto-K, enriquecida em LILE. As características geoquímicas e as idades U-Pb obtidas permitem uma correlação tectônica da Unidade Quirino com granitóides cálcio-alcalinos relacionados a arcos magmáticos, gerado durante a Orogênese Transamazônica $(2,2$ - 1,9 Ga). Idades entre 605-503 Ma (dados U-Pb em zircão e titanita) indicam retrabalhamento da Unidade Quirino durante a Orogênese Brasiliana (700-450 Ma).
\end{abstract}

Palavras-chaves: Faixa Ribeira, granitóides cálcio-alcalinos, Orogênese Tranasamazônica, Orogênese Brasiliana

\begin{abstract}
This paper presents and discusses new geochemical data from orthogneisses rocks of Paraíba do Sul Complex (PSC) from the NW of the Rio de Janeiro State, denominated Quirino Unit. U-Pb geochronological data (carried out on GEOTOP-UQAM, Canada), displayed in Valladares (1996) and Machado et al. (1996), are also discuss. This Unit, as well the Metasedimentary Unit of PSC and intrusive brazilian granitoids, comprise the Paraíba do Sul Tectonic Domain (PSTD) or Upper Tectonic Domain, at the central segment of the Ribeira belt. The Quirino Unit occurs as extensive bodies of homogeneous gneisses of upper amphibolite facies metamorphism, with hornblende and or biotite comprising approximately $50 \%$ of the studied area and ca. $70 \%$ of the PSTD. This unit yields $\mathrm{U}-\mathrm{Pb}$ zircon ages of $2185 \pm 3 \mathrm{Ma}$ and $2169 \pm 3 \mathrm{Ma}$, temporally related to the Transamazonian event. Minimum ages of $2846 \mathrm{Ma}$ and $2981 \mathrm{Ma}$ (zircon U-Pb data) reveal the pre-existence of Archean crust as Pb source of part of the investigated gneisses. Geochemical studies of orthogneisses Quirino discriminate two calc-alkaline suites: one of medium to high-K and other of high-K, with enrichment in LILE. The chemical characteristics and the ages U-Pb allow to perform a tectonic correlation of the Quirino Unit with arc magmatic calc-alkaline granitoids, which were generated during the Transamazonian orogeny $(2.2-1.9 \mathrm{Ga})$. Ages between 605-503 Ma (zircon and sphene U-Pb data) indicate reworking of Quirino Unit during Brazilian Orogeny (ca. 700-450 Ma).
\end{abstract}

Keywords: Ribeira belt, calc-alkaline granitoids, Transamazonian Orogeny, Brazilian Orogeny.

\section{INTRODUCTION AND GEOLOGIC SETTING}

This paper presents the new geochemical data, and discuss $\mathrm{U}-\mathrm{Pb}$ zircon and sphene ages, obtained by Valladares (1996) and Machado et al. (1996), for the orthogneissic rocks of the Paraiba do Sul Complex. The Paraíba do Sul Complex (Rosier 1957) occurs within the Paraíba do Sul domain (PSD) (Heilbron 1993) or upper domain (Heilbron 1995), at the central segment of the Ribeira Belt (Cordani et al. 1973), southeast Brazil, Figure la and $1 \mathrm{~b}$.

The PSD comprises the uppermost thrust sheet of Ribeira Belt, imbricated SE/NW towards the São Francisco Craton (Almeida 1977), and emplaced under amphibolite grade metamorphic conditions. This Complex displays two genetically rock sequences: the basal gneissic-migmatitic one, denominated Quirino Unit (Valladares 1996), comprising homogeneous hornblende-biotite gneiss of tonalitic/granodioritic to granitic composition, with mafic and calc-silicate enclaves; and the Metasedimentary Unit, which includes me- tasedimentary biotite gneiss with concordant intercalations of holo-leucogranite layers (Tres B arras Unit) and metapelites containing calc-silicate and sacaroidal marble lenses (São João Unit). The first sistematic geological cartography (scale 1:50.000) in the southwest of Rio de Janeiro State was executed by DRM/RJ, who denomineted this region as Bloco Angra dos Reis (Castro et al. 1984). The Paraíba do Sul shear zone (Almeida et al. 1975; Campanha \& Ferrari 1984), a D3 related megastructure, divides the PSD in two subdomains: the Northern Paraíba and the Southern Paraíba (Machado \& Demange 1991). The mapped area, where were done the geochemical studies (south of Volta Redonda 1:50,000 quadrangle, Fig. 2) is located in the latter.

\section{SAMPLING AND ANALYTICAL PROCEDURES}

The new geochemical studies were concentrated on the gneissic rocks of Quirino Unit. Were select 5 samples of homblende tonalitic-granodioritic gneisses and 11 samples of

\footnotetext{
* Departamento de Geologia Regional e Geotectônica, Faculdade de Geologia, Universidade do Estado do Rio de Janeiro (UERJ). Rua São Francisco Xavier, 524, sala A 4006. Maracanã, Rio de Janeiro, RJ, CEP 20550-900 Telefone (Fax): 0055 (021)-2546675, tel 021 587-7102, Brasil.

** Departamento de Geologia Geral, Institute de Geociências, Universidade de São Paulo (USP). Rua do Lago, 562. Cidade Universitana, São Paulo, SP, CEP 05422-970, Caixa Postal: 11.348. Telefone 0055-011-8183994, FAX: 011-8183993, Brasil.
} 
A
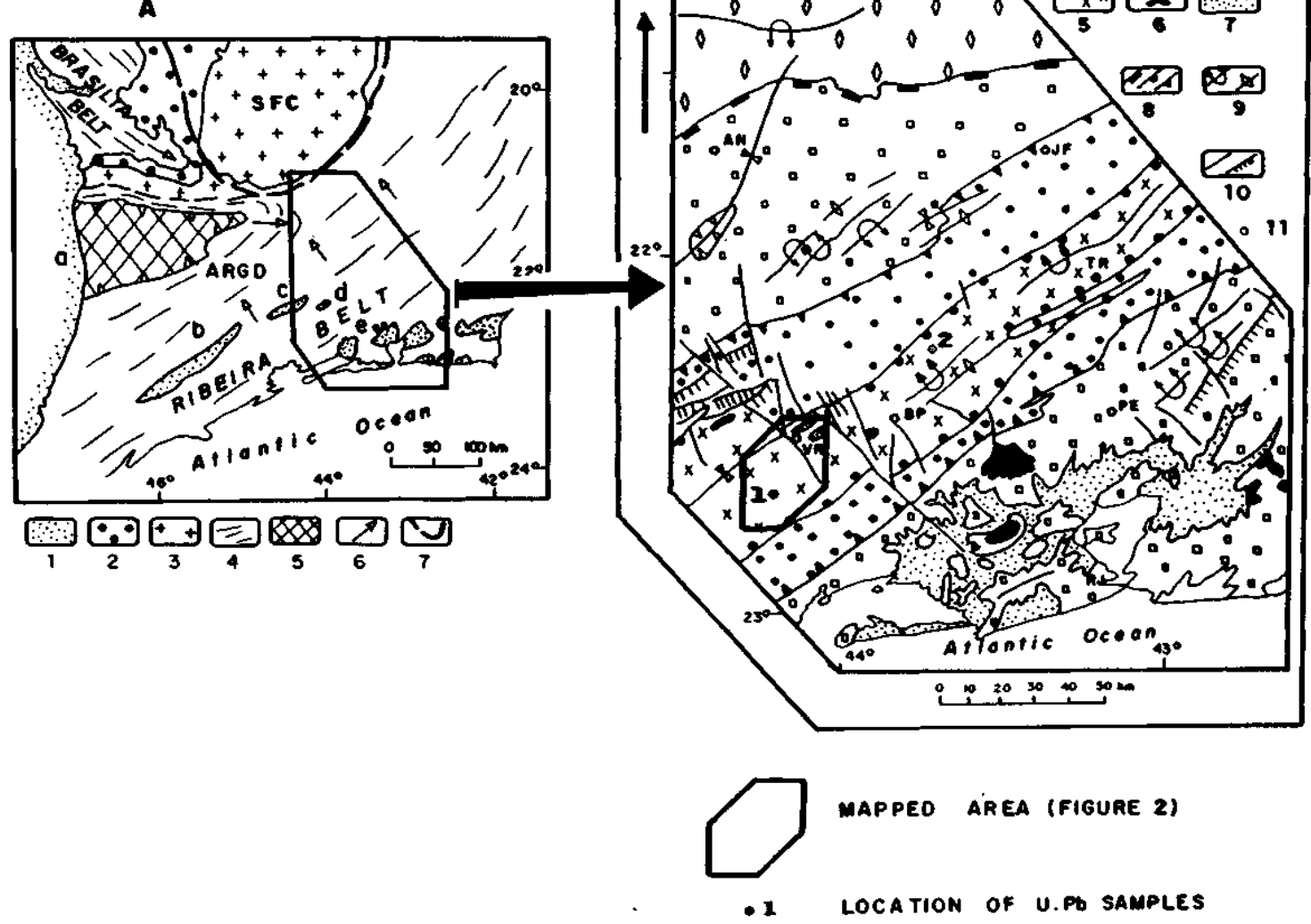

Figure 1a - Simplified Tectonic Map of Southeastern Brazil apresented in Heilbron (1995). This map was compiled and integrated from Hasui \& Oliveira (1984), Campos Neto (1992), Valeriano et al. (1993), Trouw et al. (1994). The inset shows the localization of the segment central of Ribeira Belt, studied by Heilbron (1995). Legend:1- Phanerozoic covers, a-Parand basin, b, c, $d$ and e-Taubate, Resende, Volta Redonda and Guanabara rifts; 2-Bambui group; 3- cratonic basement; 4-Brazilian fold belts (ARGD-Alto Rio Grande Domain); 5- Guaxupé nappe; 6- main vergence; 7- São Francisco Craton limit.

Figure la-Tectonic Compartmentation proposed by Heilbron (1995) for the central segment ofRibeirafold belt, with the localization of investigated area and the U-Pb samples. Legend: 1- São Francisco craton; 2-authochtonous domain; 3- lower domain or Andrelandia Tectonic Domain; 4- central domain orJuiz de Fora domain; 5- upper domain or Paraiba do Sul domain; 6-Meso-Cenozoic alkaline rocks; 7- Phanerozoic covers; 8 - Major thrust shear zones; 9- Major late deformation axial traces; 10- brittle phanerozoic faults; 11- cities: SJ - São João del Rei; AN - Andrelandia; JF -Juiz de Fora; VR - Volta Redonda; BP - Barra do Piraí; TR -Três Rios; PE - Petrópolis; RJ - Rio de Janeiro. Figura la- Mapa tectônico simplificado do sudeste brasileiro, apresentado em Heilbron (1995), compilado e integrado com dados de Hasui \& Oliveira (1984); Campos Neto (1992); Valeriano et al. (1993); Trouw et al. (1984). A inserção mostra o segmento central da Faixa Ribeira, área estudada por Heilbron (1995). Legenda: 1-Coberturas Fanerozóicas: a- Bacia do Paraná, b, c, d e e-Taubaté, Resende, Volta Redonda e Rift da Guanabara; 2-Grupo Bambuí; 3- Embasamento Cratônico; 4 - Cinturões Brasilianos (ARGD - Domínio Alto Rio Grande); 5- Nappe de Guaxupé; 6- Direção principal de vergência; 7- Limite do Cráton do São Francisco Figura 1b- Organização tectônica proposta por Heilbron (1995) para o segmento central da Faixa Ribeira, com localização da área mapeada e Iocalização dos pontos com geocronologia U-Pb. Legenda: 1- Cráton do São Francisco; 2- Domínio Autóctone; 3- Domínio Inferior ou Domínio Andrelândia; 4- Domínio Intermediário ou Domínio Juiz de Fora; 5- Domínio Superior ou Domínio Paraíba do Sul; 6-Rochas Alcalinas Meso-Cenozóicas; 7- Coberturas Fanerozóicas; 8- Zonas de Cisalhamento principals de baixo angulo (Empurrão); 9- Traços axiais de deformação tardia; 10- Falhas no Fanerozóico; 11- Cidades: SJ - São João del Rei; AN - Andrelândia; J - Juiz de Fora; VR - Volta Redonda; BP - Barra do Piraí; TR - Três Rios; PE -Petropólis; RJ - Rio de Janeiro. 


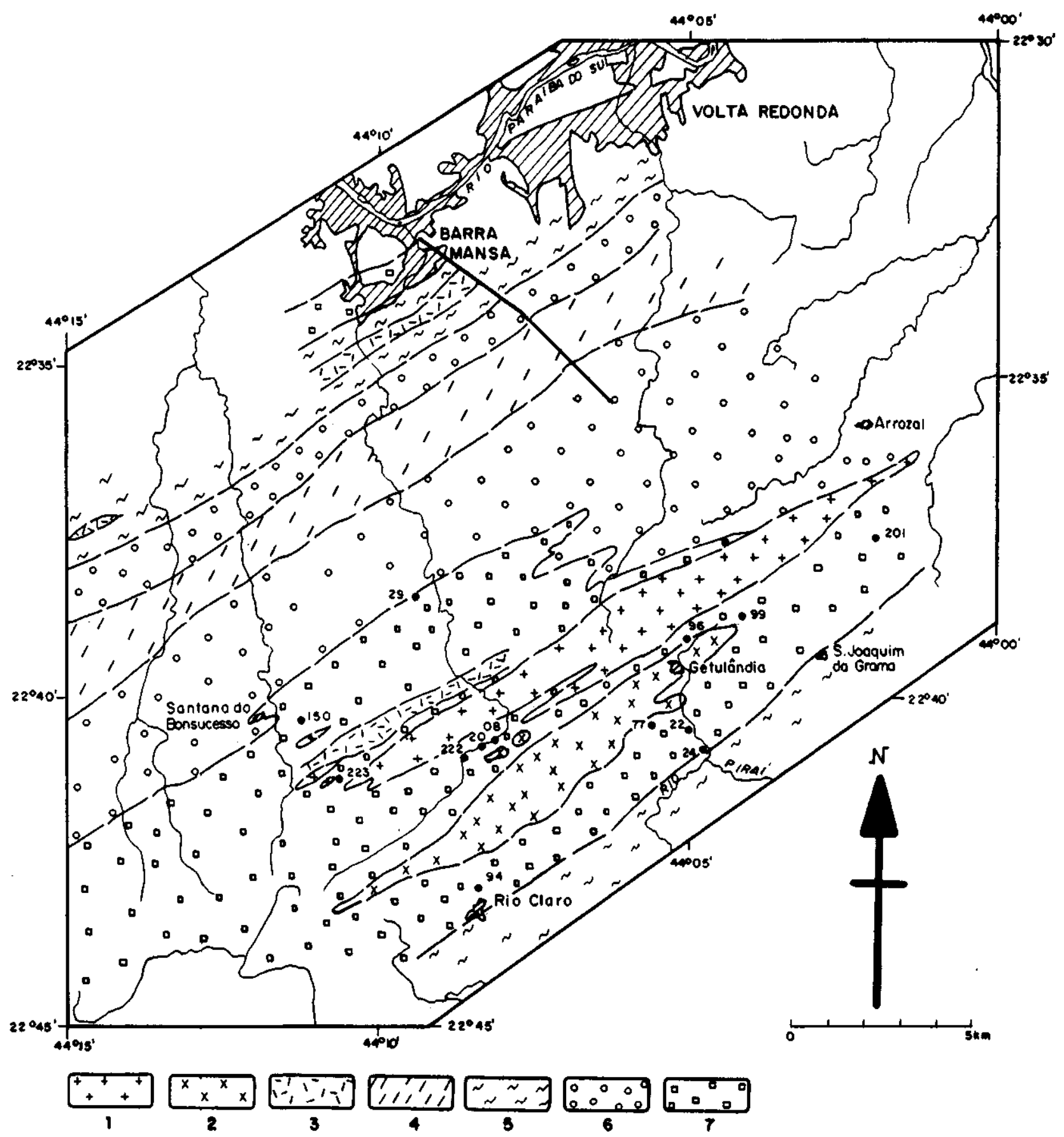

Figure 2- Geologic Map of the investigated area (south of Volta Redonda 1:50,000 quadrangle), presented in Valladares (1996). Legend: 1-Fortaleza Granite; 2- Getulândia Granite; 3- Rio Turvo granitoids; 4- Resgate granitoid; 5- São João Unit; 6- Três Barras Unit; 7- Quirino Unit. The numbers in the map are indicative of geochemical samples.

Figura 2- Mapa geológico da área investigada (sul da Folha Volta Redonda 1:50.000), apresentado em Valladares (1996). Legenda 1- Granito Fortaleza; 2- Granito Getulândia; 3- Granitóide tipo Rio Turvo; 4 Granitóide Resgate; 5- Unidade São João; 6- Unidade Três Barras; 7-Unidade Quirino. Os números no mapa indicam amostras com análises geoquímicas.

biotite granitic gneisses (Fig. 2), including 2 samples of melanossomes. U-Pb geocronological analyses, presented in Valladares (1996) and Machado et al. (1996), were carried out on a sample of hornblende gneiss (Conceição quarry near Valença, state of Rio de Janeiro, sample 2, Fig. 1b) located on Northern Paraiba Domain, and a sample of biotite gneiss collected near the village of Bom Sucesso (sample 150, Fig. 2, sample 1, Fig. 1b), Southern Paraíba Domain. The horn- blende gneisses are similar to the inferior lithostructural unit of Paraíba do Sul Complex, described as Quirino Sequence by Machado (1986) in Valenga, State of Rio de Janeiro. Based on field observations, Heilbron et al. (1991) and Heilbron (1993) suggest that the gneisses of Quirino Unit are intrusive into the metasedimentary units as they contain xenoliths similar in composition to the surrounding metasedimentary rocks. 
The chemical analyses were carried out at ACT LABS (Canada) for major, trace and rare earth element. The major and some trace elements were measured using ICP fusion and total digestion. The trace elements with minor concentration and the rare earth element were detected by (INAA). During this project, external quality control was performed by inclusion of M. Figueiredo's personal patterns. The abundance patterns of REE were done using the concentration values proposed by Boynton (1984) for chondrite normalization. For calculation of the possible $\mathrm{Eu}$ anomaly, by the $\mathrm{Eu} / \mathrm{Eu}^{*}$ ratio, the $\mathrm{Eu}^{*}$ value was determined by linear interpolation between $\mathrm{Sm}$ and $\mathrm{Tb}$, because $\mathrm{Gd}$ was not analysed. This procedure was previously used by Marques (1988).

The U-Pb geochronological analyses were carried out at GEOTOP-UQAM, Canada. The analytical techniques include: crystal selection, chemistry, mass spectrometry and data treatment. These techniques followed previously described procedures (Corfu \& Stott 1986, Krogh 1973, Krogh 1982, Machado et al. 1989). Avarage analytical precision at $95 \%$ confidence level is $0.5 \%$ and $0.1 \%$ for $\mathrm{U}-\mathrm{Pb}$ and ${ }^{207} \mathrm{~Pb} /{ }^{206} \mathrm{~Pb}$, respectively. Regression lines and intercepts were calculated using the method proposed by Davis (1982). Precision of the ages is quoted at $95 \%$ confidence level.

\section{RESULTS Geochemical characteristics}

Geochemical analyses on major and trace elements, including REE, of 16 gneissic rocks of the Quirino Unit were carried out at the investigated area. The new data from the Quirino orthogneisses at the Paraíba do Sul domain (Figs. 1b and 2) discriminate two calc-alkaline suites (Fig. 3): one of medium to high-K (Table 1) and another of high-K, with enrichment in LILE (Table 2). The major element abundances indicate that these rocks bear characteristics of metaluminous to

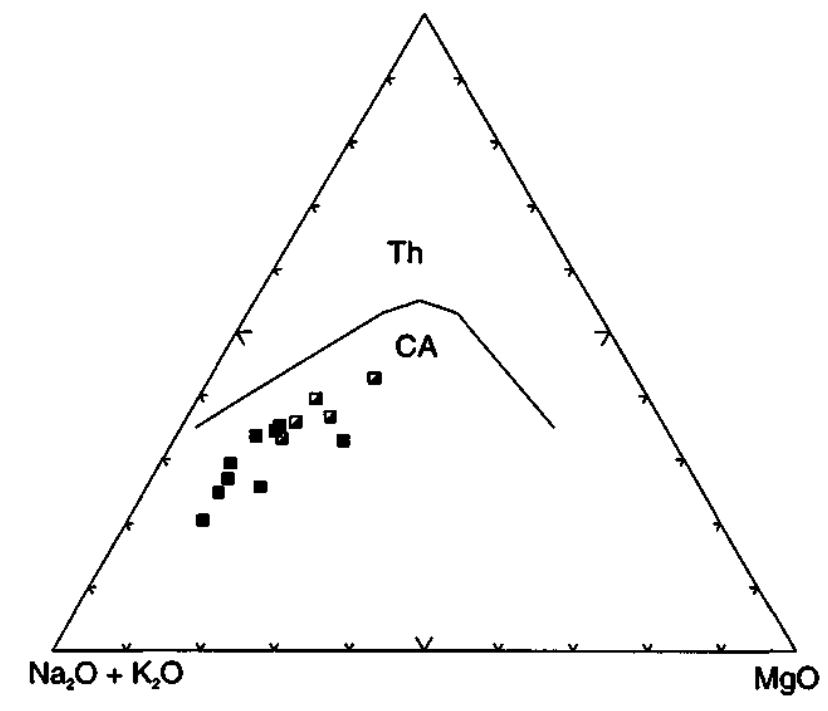

$\mathrm{FeO}^{*}$

Figure 3 - AFM diagram (Irvine \& Baragar 1971) for the orthogneisses of Quirino Unit. CA-TH: boundary between calc-alkaline and tholeiitic series. Legend: half filled square

- medium to high K calc-alkaline suite; filled square - high K calc-alkaline suite.

Figura 3 - Diagrama AFM para os ortognaisses da Unidade Quirino. CA-TH: limite entre as séries cálcio-alcalina e toleítica. Legenda: quadrados metade preenchidos - suíte cálcio-alcalina de médio a alto-K; quadrados preenchidos - suíte cálcio-alcalina de alto-K.
Table 1-Chemical compositions for the medium to high-K calc-alkaline orthogneisses suite of the Quirino Unit.

Tabela 1- Composições químicas para os ortognaisses da Unidade Quirino da suíte cálcio-alcalina de médio a alto-K.

\begin{tabular}{|c|c|c|c|c|c|}
\hline $\begin{array}{l}\text { Sample } \\
\text { Number }\end{array}$ & $\begin{array}{c}1 \\
\text { VR-22b }\end{array}$ & $\stackrel{2}{\text { VR-96 }}$ & $\stackrel{3}{\text { VR-24 }}$ & $\begin{array}{c}4 \\
77\end{array}$ & $\begin{array}{c}5 \\
\text { VR-20 }\end{array}$ \\
\hline $\mathrm{SiO}_{2}$ & 57,39 & 58,40 & 61,15 & 64,13 & 67,41 \\
\hline $\mathrm{TiO}_{2}$ & 0,93 & 1,09 & 0,81 & 0,64 & 0,62 \\
\hline $\mathrm{Al}_{2} \mathrm{O}_{3}$ & 18,66 & 15,31 & 16,07 & 16,17 & 14,10 \\
\hline $\mathrm{Fe}_{2} \mathrm{O}_{3} *$ & 7,1 & 8,47 & 5,69 & 5,11 & 4,69 \\
\hline $\mathrm{MnO}$ & 0,11 & 0,18 & 0,12 & 0,11 & 0,07 \\
\hline $\mathrm{MgO}$ & 2,57 & 3,94 & 2,69 & 1,90 & 1,77 \\
\hline $\mathrm{CaO}$ & 4,47 & 5,13 & 4,61 & 3,95 & 3,11 \\
\hline $\mathrm{Na}_{2} \mathrm{O}$ & 4,32 & 3,50 & 3,51 & 4,50 & 2,91 \\
\hline $\mathrm{K}_{2} \mathrm{O}$ & 2,90 & 2,78 & 2,64 & 2,68 & 2,88 \\
\hline $\mathrm{P}_{2} \mathrm{O}_{5}$ & 0,50 & 0,32 & 0,28 & 0,20 & 0,26 \\
\hline PF & 0,90 & 1,10 & 1,16 & 0,97 & 0,80 \\
\hline TOTAL & 99,85 & 100,22 & 98,73 & 100,36 & 98,62 \\
\hline $\mathrm{Cr}$ & 19 & 153 & 28 & 7 & 38 \\
\hline $\mathrm{Ni}$ & 10 & 4 & 20 & 9 & 11 \\
\hline Co & 33 & 23 & 32 & 19 & 34 \\
\hline v & 121 & 48 & 126 & 89 & 84 \\
\hline $\mathrm{Cu}$ & 31 & 8 & 4 & 19 & 3 \\
\hline $\mathrm{Pb}$ & 19 & 19 & 11 & 11 & 20 \\
\hline $\mathrm{Zn}$ & 218 & 74 & 87 & 90 & 101 \\
\hline $\mathbf{K}$ & 24506 & 23484 & 22593 & 22499 & 24559 \\
\hline $\mathbf{R b}$ & 132 & 142 & 110 & 81 & 195 \\
\hline $\mathrm{Ba}$ & 816 & 536 & 718 & 584 & 352 \\
\hline $\mathrm{Sr}$ & 389 & 473 & 442 & 386 & 187 \\
\hline $\mathbf{T a}$ & 0,31 & 0,61 & 0,93 & 0.7 & 2,47 \\
\hline $\mathrm{Nb}$ & 5,2 & 10,4 & 15,8 & 12 & 41,9 \\
\hline Hf & 3,26 & 5,49 & 4,33 & 5,43 & 5,96 \\
\hline $\mathbf{Z r}$ & 156 & 178 & 139 & .148 & 195 \\
\hline$Y$ & 29 & 26 & 16 & 22 & 27 \\
\hline Th & 18,32 & 7,94 & 12,37 & 7,24 & 8,73 \\
\hline $\mathbf{U}$ & 1,83 & 1,02 & 2,16 & 1,51 & 1,75 \\
\hline K/Rb & 185 & 165 & 204 & 276 & 126 \\
\hline La & 63,42 & 43,25 & 33,71 & 27,57 & 24,76 \\
\hline $\mathrm{Ce}$ & 123,17 & 82,42 & 65,98 & 60,37 & 53,42 \\
\hline Nd & 50,9 & 34,6 & 24,74 & 26,16 & 21,57 \\
\hline $\mathrm{Sm}$ & 10,18 & 7,43 & 5,05 & 5,94 & 5,34 \\
\hline Eu & 1,6 & 1,25 & 1,12 & 1,24 & 0,88 \\
\hline $\mathbf{T b}$ & 1,43 & 0,92 & 0,62 & 0,91 & 0,92 \\
\hline $\mathbf{Y b}$ & 1,95 & 1,82 & 2,04 & 1,48 & 1,61 \\
\hline Lu & 0,29 & 0,28 & 0,3 & 0,22 & 0,24 \\
\hline $\mathrm{Yb}_{\mathbf{N}}$ & 9,26 & 9,11 & 9,69 & 7,06 & 7,63 \\
\hline LaN & 203,1 & 138,32 & 108,1 & 88,93 & 79,48 \\
\hline $\mathrm{La}_{\mathrm{N}} / \mathrm{Yb}_{\mathrm{N}}$ & 21,93 & 15,18 & 11,15 & 12,59 & 10,41 \\
\hline $\mathrm{Lan}_{\mathrm{N}} / \mathbf{S m}_{\mathrm{N}}$ & 3,89 & 3,63 & 4,17 & 2,92 & 2,9 \\
\hline$S m N / L u N$ & 5,8 & 4,38 & 2,78 & 4,46 & 3,67 \\
\hline $\mathrm{Eu} / \mathrm{Eu}^{*}$ & 0,55 & 0,63 & 0,68 & 0,71 & 0,52 \\
\hline
\end{tabular}


Table 2-Chemical compositions for the high-K calc-alkaline orthogneisses suite of the Quirino Unit.

Tabela 2- Composições químicas para os ortognaisses da Unidade Quirino da suíte cálcio-alcalina de alto-K.

\begin{tabular}{|c|c|c|c|c|c|c|c|c|c|c|c|}
\hline $\begin{array}{l}\text { Sample } \\
\text { number }\end{array}$ & $\begin{array}{c}1 \\
150 c\end{array}$ & $\stackrel{2}{223 c}$ & $\begin{array}{c}3 \\
150 a\end{array}$ & $\begin{array}{c}4 \\
94 a\end{array}$ & $\underset{29 b}{5}$ & $\begin{array}{c}6 \\
201 a\end{array}$ & $\begin{array}{c}7 \\
150 \mathrm{~b}\end{array}$ & $\begin{array}{c}8 \\
99\end{array}$ & $\stackrel{9}{222 a}$ & $\begin{array}{c}10 \\
223 a\end{array}$ & $\begin{array}{l}11 \\
08\end{array}$ \\
\hline $\mathrm{SiO}_{2}$ & 47,65 & 48,20 & 59,53 & 61,06 & 65,57 & 67,25 & 66,24 & 67,65 & 68,63 & 69,43 & 71,77 \\
\hline $\mathrm{TiO}_{2}$ & 1,59 & 1,47 & 0,95 & 0,93 & 0,42 & 0,96 & 0,61 & 0,79 & 0,55 & 0,38 & 0,66 \\
\hline $\mathrm{Al}_{2} \mathrm{O}_{3}$ & 11,37 & 10,23 & 15,53 & 15,86 & 15,68 & 14,53 & 13,69 & 14,70 & 14,74 & 13,94 & 13,07 \\
\hline $\mathrm{Fe}_{2} \mathrm{O}_{3} *$ & 10,25 & 8,91 & 6,47 & 5,89 & 3,95 & 4,97 & 3,91 & 4,05 & 3,29 & 2,72 & 4,41 \\
\hline $\mathrm{MnO}$ & 0,36 & 0,20 & 0,13 & 0,11 & 0,06 & 0,08 & 0,04 & 0,06 & 0,09 & 0,09 & 0,06 \\
\hline $\mathrm{MgO}$ & 9,96 & 10,59 & 4,03 & 1,98 & 1,38 & 1,43 & 2,11 & 1,18 & 1,22 & 1,23 & 1,50 \\
\hline $\mathrm{CaO}$ & 8,35 & 9,42 & 4,19 & 4,01 & 2,64 & 2,32 & 2,00 & 2,25 & 2,73 & 2,12 & 2,34 \\
\hline $\mathrm{Na}_{2} \mathrm{O}$ & 1,14 & 0,74 & 3,34 & 3,93 & 3,71 & 2,43 & 2,69 & 2,92 & 2,84 & 2,75 & 2,34 \\
\hline $\mathrm{K}_{2} \mathrm{O}$ & 6,22 & 6,94 & 4,48 & 3,80 & 4,58 & 4,94 & 5,40 & 4,66 & 4,96 & 5,58 & 3,72 \\
\hline $\mathrm{P}_{2} \mathrm{O}_{5}$ & 1,30 & 1,66 & 0,72 & 0,36 & 0,28 & 0,36 & 0,10 & 0,30 & 0,26 & 0,24 & 0,12 \\
\hline $\mathbf{P F}$ & 1,64 & 1,14 & 1,38 & 2,06 & 0,90 & 1,09 & 0,88 & 1,06 & 0,75 & 1,30 & 1,03 \\
\hline TOTAL & 99,83 & 99,49 & 100,75 & 99,99 & 99,17 & 100,36 & 97,68 & 99,62 & 100,06 & 99,78 & 100,98 \\
\hline $\mathrm{Cr}$ & 439 & 519 & 131 & 26 & 13 & 25 & 5 & 20 & 18 & 25 & 44 \\
\hline $\mathrm{Ni}$ & 222 & 201 & 62 & 9 & 12 & 7 & 7 & 46 & 10 & 12 & 16 \\
\hline Co & 44 & 44 & 29 & 32 & 18 & 19 & 20 & 15 & 23 & 38 & 52 \\
\hline$v$ & 182 & 168 & 92 & 98 & 56 & 59 & 44 & 135 & 53 & 38 & 85 \\
\hline $\mathrm{Cu}$ & 54 & 13 & 8 & 15 & 38 & 10 & 1 & 1 & 41 & 83 & 34 \\
\hline $\mathrm{Pb}$ & 15 & 22 & 15 & 18 & 24 & 25 & 31 & 5 & 28 & 30 & 28 \\
\hline $\mathbf{Z n}$ & 147 & 183 & 114 & 99 & 52 & 83 & 63 & 135 & 49 & 73 & 70 \\
\hline $\mathbf{K}$ & 52065 & 59108 & 37672 & 32407 & 38846 & 41518 & 46502 & 30411 & 41598 & 47166 & 31034 \\
\hline $\mathbf{R b}$ & 359 & 376 & 262 & 143 & 188 & 222 & 258 & 254 & 181 & 210 & 190 \\
\hline $\mathrm{Ba}$ & 1908 & 2452 & 1108 & 1216 & 1249 & 912 & 1134 & 570 & 1627 & 1225 & 682 \\
\hline $\mathrm{Sr}$ & 467 & 520 & 585 & 534 & 433 & 190 & 317 & 152 & 384 & 343 & 202 \\
\hline $\mathrm{Ta}$ & 1,2 & 0,81 & 2,72 & 1,33 & 0,31 & 1,51 & 1,14 & 1,93 & 1,01 & 0,91 & 1,4 \\
\hline $\mathrm{Nb}$ & 20,4 & 13,8 & 46,2 & 22,6 & 5,2 & 25,7 & 19,3 & 32,8 & 17,1 & 15,5 & 23,8 \\
\hline $\mathrm{Hf}$ & 7,98 & 10,17 & 6,24 & 8,99 & 8,14 & 10,07 & 10,33 & 8,42 & 7,05 & 5,99 & 8,4 \\
\hline $\mathrm{Zr}$ & 338 & 369 & 298 & 381 & 323 & 397 & 429 & 306 & 234 & 171 & 265 \\
\hline $\mathbf{Y}$ & 36 & 35 & 97 & 27 & 26 & 34 & 27 & 34 & 20 & 14 & 24 \\
\hline Th & 9,88 & 28,47 & 4,83 & 14,3 & 48,85 & 46,34 & 72,32 & 41,6 & 31,22 & 33,51 & 24,01 \\
\hline $\mathbf{U}$ & 6,49 & 4,17 & 5,53 & 3,98 & 4,38 & 4,94 & 6,82 & 6,7 & 3,73 & 3,35 & 7 \\
\hline $\mathbf{K} / \mathbf{R b}$ & 143 & 156 & 143 & 225 & 206 & 186 & 178 & 155 & 229 & 224 & 162 \\
\hline La & 81,64 & 119,97 & 37,13 & 36,35 & 143,48 & 85,63 & 141,54 & 70,92 & 77,53 & 58,49 & 57,43 \\
\hline $\mathrm{Ce}$ & 168,66 & 233,83 & 103,65 & 88,84 & 261,52 & 188,38 & 285,15 & 157,26 & 160,1 & 105,61 & 116,06 \\
\hline Nd & 80,84 & 111,83 & 69,44 & 41,87 & 103,8 & 91,67 & 118,81 & 71,02 & 63,44 & 43,66 & 48,02 \\
\hline Sm & 15,97 & 20,33 & 18,11 & 8,58 & 17,3 & 16,12 & 21,7 & 13,19 & 11,08 & 8,33 & 8,8 \\
\hline Eu & 2,89 & 3,52 & 1,71 & 1,81 & 2,08 & 1,64 & 1,55 & 1,06 & 1,64 & 1,52 & 1,17 \\
\hline $\mathrm{Tb}$ & 1,8 & 1,83 & 2,82 & 1,02 & 1,32 & 1,51 & 1,76 & 1,32 & 1,11 & 0,71 & 1 \\
\hline $\mathrm{Yb}$ & 2,28 & 1,95 & 6,33 & 2,58 & 1,25 & 2,84 & 0,94 & 2,39 & 1,74 & 0,88 & 1,45 \\
\hline Lu & 0,32 & 0,26 & 0,84 & 0,41 & 0,15 & 0,49 & 0,15 & 0,36 & 0,28 & 0,12 & 0,25 \\
\hline $\mathrm{Yb}_{\mathrm{N}}$ & 10,87 & 9,30 & 30,20 & 12,30 & 7,25 & 13,54 & 4,48 & 11,40 & 8,30 & 4,19 & 6,92 \\
\hline LaN & 263 & 383 & 119 & 117 & 461 & 276 & 454 & 228 & 250 & 188 & 185 \\
\hline LaN $/ Y b_{N}$ & 24,22 & 41,61 & 3,88 & 9,53 & 63,62 & 20,40 & 101,91 & 20,07 & 30,13 & 45,03 & 26,77 \\
\hline $\mathrm{LaN} / \mathrm{SmN}$ & 3,22 & 3,67 & 1,28 & 2,66 & 5,20 & 3,34 & 4,08 & 3,37 & 4,40 & 4,40 & 4,39 \\
\hline$S \mathrm{~m} N / \mathrm{LuN}_{\mathrm{N}}$ & 8,24 & 12,92 & 3,56 & 3,46 & 19,08 & 5,44 & 23,93 & 6,05 & 6,53 & 11,48 & 5,43 \\
\hline $\mathrm{Eu} / \mathrm{Eu} *$ & 0,71 & 0,76 & 0,32 & 0,81 & 0,58 & 0,44 & 0,33 & 0,34 & 0,62 & 0,66 & 0,54 \\
\hline
\end{tabular}




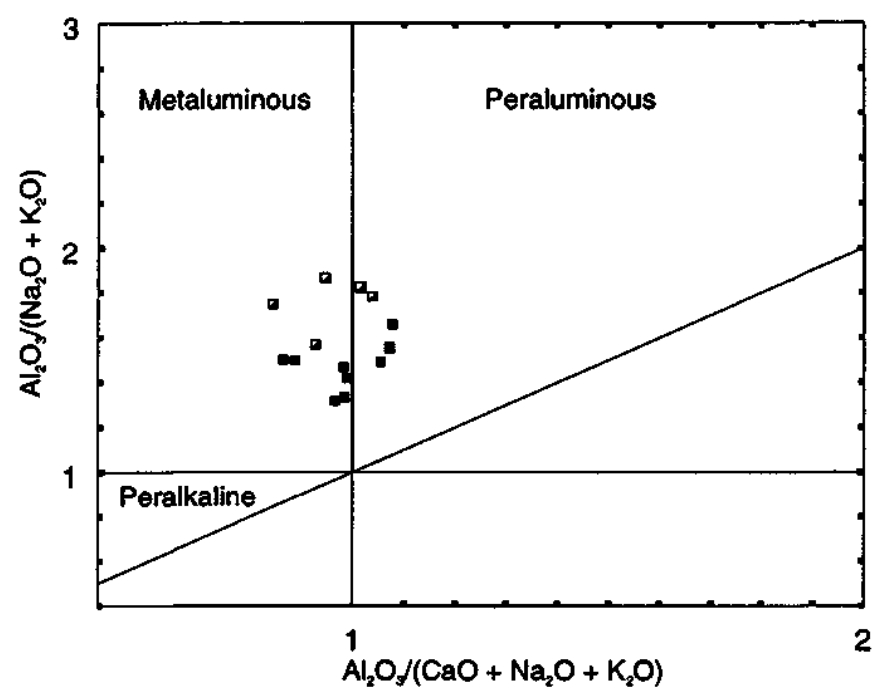

Figure 4 - Shand's indice diagram (Maniar \& Piccoli 1989) for the orthogneisses of Quirino Unit. Same symbols as in Fig 3.

Figura 4 - Diagrama de índice de Shand (Maniar \& Piccoli 1989) para os ortognaisses da Unidade Quirino. Mesmos símbolos que os da figura 3.

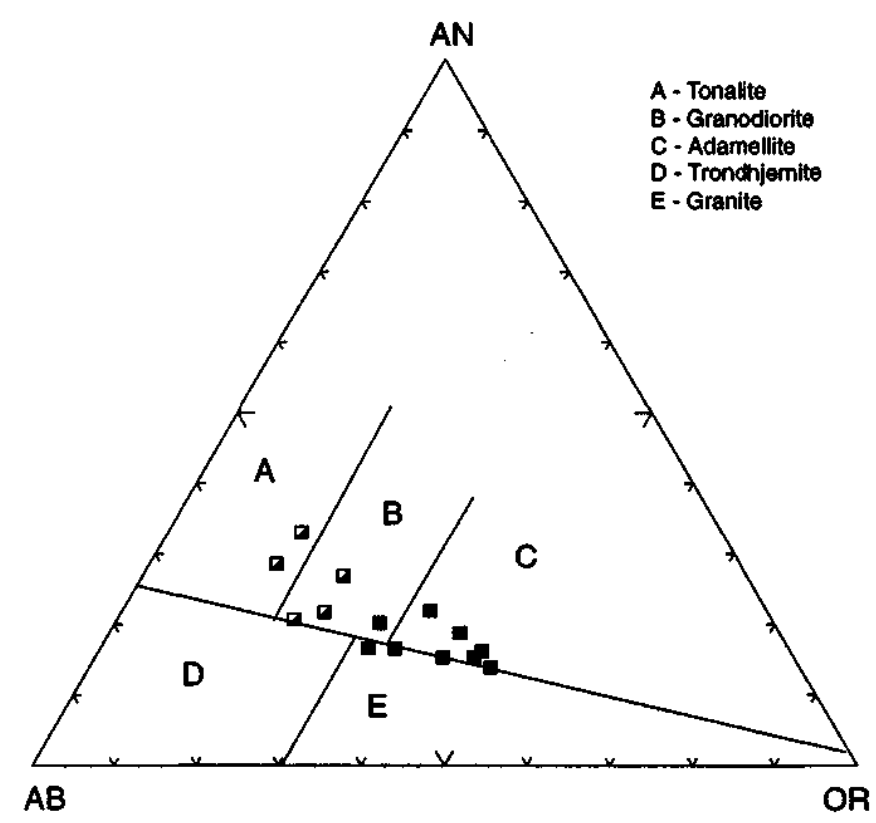

Figure 5 - O'Connor's (1965) An-Ab-Or normative classificatory diagram for the orthogneisses of Quirino Unit. Same symbols as in Fig 3.

Figura 5 - Diagrama normative AN-AB-OR (O'Connor 1965) para os ortognaisses da Unidade Quirino. Mesmos símbolos que os da figura 3.

slightly peraluminous granitoids, with $\mathrm{Al}_{2} \mathrm{O}_{3} /\left(\mathrm{CaO}+\mathrm{K}_{2} \mathrm{O}+\right.$ $\mathrm{Na}_{2} \mathrm{O}$ ) molar percentage of 0.97 (Fig. 4).

The medium to high- $\mathrm{K}$ calc-alkaline suite comprises predominantly intermediate terms with composition of tonalitic to granodioritic gneisses (Fig. 5). The $\mathrm{SiO}_{2}$ content (anhydrous base) varies between 58 and $69 \%, \mathrm{Na}_{2} \mathrm{O}$ between 3 and $4,5 \%$, and $\mathrm{K}_{2} \mathrm{O} 3 \%$, in media. The main characteristics are $\mathrm{K}_{2} \mathrm{O} / \mathrm{Na}_{2} \mathrm{O}<1 ; \mathrm{Al}_{2} \mathrm{O}_{3}>14 \% ; \mathrm{CaO}$ between 3-5\%; $\mathrm{Fe}_{2} \mathrm{O}_{3}$ between 5-9\%, and Cr between 19-153ppm (Table 1, Figs. 6 and 7). In terms of incompatible elements this suite displays 110-195ppm Rb, 352-8 16ppm Ba, 139-195ppm Zr and 819ppm Th, (Table 1, Fig. 7).

Chondrite-normalized REE patterns are moderately fractionated $(\mathrm{LaN} / \mathrm{YbN}=22-10)$, with flat HREE $(\mathrm{YbN}=9-7)$ patterns, and negative $\mathrm{Eu}$ anomaly $\left(\mathrm{Eu} / \mathrm{Eu}^{*}=0,52-0,68\right)$. The less differenciated terms display $\mathrm{LaN}$ values of about 200 times chondrite (Fig. 8). The total REE content, the Eu content, and fractionation decrease with differenciation. Decreasing REE contents with differenciation have been found in many calc-alkaline gneissic sequences (e. g., Arth et al. 1978, Condie et al. 1982, Figueiredo \& Campos Neto 1993) and are generally considered as representing crystal-liquid equilibrium of igneous protolith, being either the result of partial melting of a mafic source or fractional crystallization of basic magmas.

The high-K calc-alkaline suite comprises predominantly acidic terms (adamellitic-granitic gneisses, Fig. 5). With exception of the melanossomes (samples 1 and 2, Table 2), that will be discuss latter, the $\mathrm{SiO}_{2}$ content (anhydrous base) varies between 59 and $72 \%, \mathrm{Na}_{2} \mathrm{O}$ between 2 and $5 \%, \mathrm{~K}_{2} \mathrm{O}$ betwwen $3-6 \%$, in media $4,75 \% ; \mathrm{K}_{2} \mathrm{O} / \mathrm{Na}_{2} \mathrm{O}>1$, and $\mathrm{CaO}$ between $2-4 \%$. This suite is enriched in incompatible elements, including LILE, REE and high field strength elements (HFSE), with 31034-47166 ppm K, 143-262 ppm Rb, 5701627 ppm Ba, 3-7 ppm U, 148-429 ppm Zr (Fig. 7, Table 2). The Th content is extremely high, up to 72ppm, Figure 7. Chondrite-normalized REE patterns are strongly fractionated with $\mathrm{LaN} / \mathrm{YbN}=4-100$ and $\mathrm{YDN}=4$ to 14 , with enrichment in LREE (LaN/SmN $=3-5$, Table 2, Figs. 9, 10 and 11). The total REE content is moderate in the intermediate terms (LaN ca. 100 times chondrite, Fig. 9), to high, in the acidic terms (LaN ca. 400 times chondrite, Figs. 10 and 11). The total Eu content decreases with differentiation, showing varying degrees of negative $\mathrm{Eu}$ anomaly $\left(\mathrm{Eu} / \mathrm{Eu}^{*}=0,32-0,81\right)$. The total content of REE and the degree of fractionation, in general terms, increase with differenciation. The melanossomes display fractionated REE patterns (LaN/YbN-24-41), are enriched in HREE, $\mathrm{YbN}=9-11$, and bear less significant $\mathrm{Eu}$ anomaly $\left(\mathrm{Eu} / \mathrm{Eu}^{*}=0,71-0,76\right)$. The total REE content is high, with LaN up to 400 times chondrite (Fig. 12).

Tectonic Setting The lithological association of medium to high-K suite is generally interpreted as being produced in a pre-plate collision environment and the lithological association of high-K calc-alkaline suite could be interpreted as being produced in a post-collision environment (Batchelor \& Bowden 1985, Fig. 13). The Ocean Ridge Granite (ORG)- normalized incompatible element distribution patterns (spidergrams, Pearce et al. 1984) for both suites exhibit enrichment of large ion lithophile element (LILE) and decreasing values for the least incompatible elements, as well as negative anomalies of $\mathrm{Mb}$ and $\mathrm{Ta}$. These features have been described for volcanic arc granites with envolvement of oceanic crust in a subduction environment. The envelope of multi-element patterns, for both suites, show similarity with granites from high $\mathrm{K}$ calc-alkaline series of active continental margins (e.g. Chile, Figs. 14 and 15).

U-Pb Geochronology The Quirino orthogneisses yield U-Pb zircon ages of $2185 \pm 3 \mathrm{Ma}$ and $2169 \pm 3 \mathrm{Ma}$ (Valladares 1996, Machado et al. 1996). These ages are defined by upper discordia intercepts, and were obtained from 


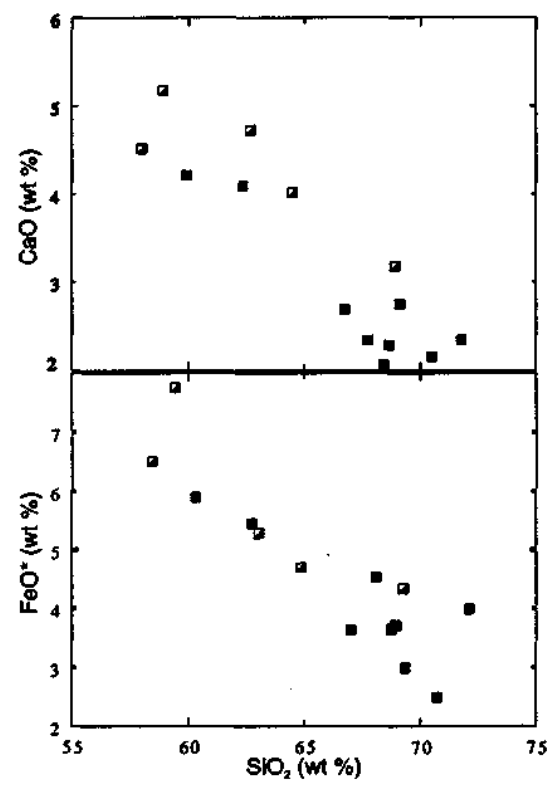

Figure 6- Variations diagrams of major elements for the orthogneisses of Quirino Unit. The line which separates the fields of medium-K and high-K, in the $\mathrm{SiO}_{2} \times \mathrm{K}_{2} \mathrm{O}$ diagram, after Le Maitre (1989). Symbols as in Fig. 3. Figura 6- Diagrama de variagao para elementos maiores dos ortognaisses da Unidade Quirino. A linha de separação entre os campos das séries médio-K e alto-K no diagrama $\mathrm{SiO}_{2}$ x K $\mathrm{K}_{2} \mathrm{O}$ segundo Le Maitre (1989). Símbolos como na figura 3 .
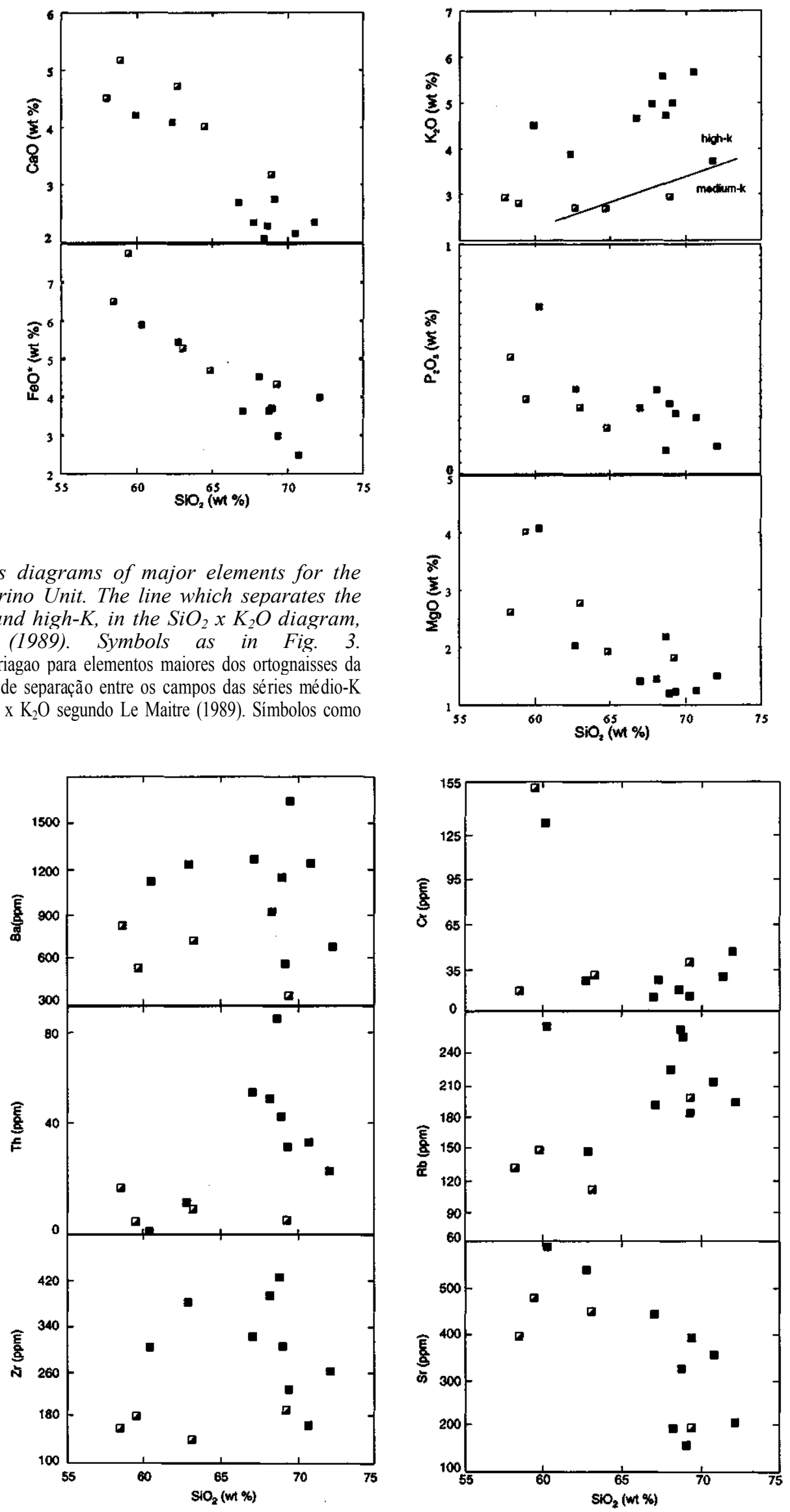

Figure 7- Variations diagrams of trace elements for the orthogneisses of Quirino Unit. Same symbols as in Fig. 3. Figura 7- Diagrama de variação para elementos traç os dos ortognaisses da Unidade Quirino. Mesmos símbolos que os da figura 3. 


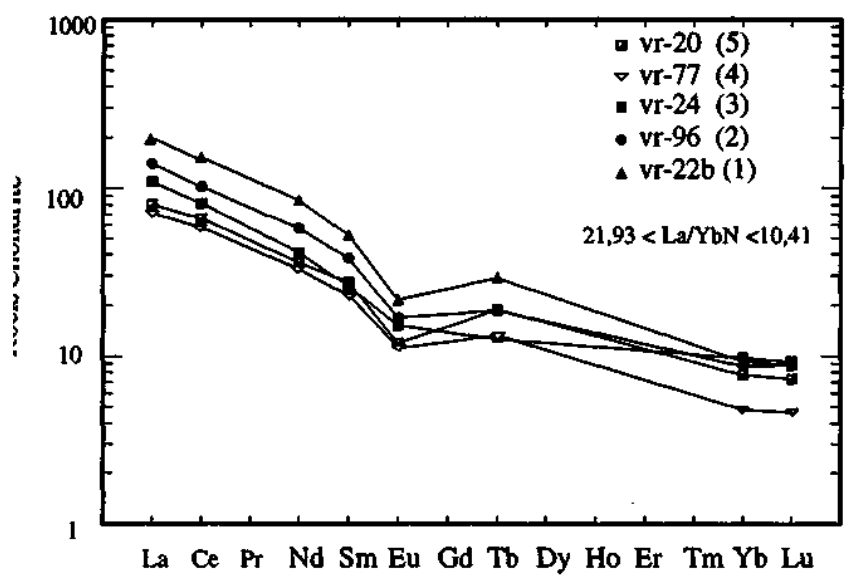

Figure 8 - Chondrite-normalized (Boynton 1984) rare earth elements (REE) distribution patterns for the medium to highK calc-alkaline suite, Quirino Unit.

Figura 8 - Padrões de distribuição de elementos de Terras Raras (ETR), normalizados para condrito (Boynton 1984), para os ortognaisses da suíte cálcio-alcalina de médio a alto-K da Unidade Quirino.

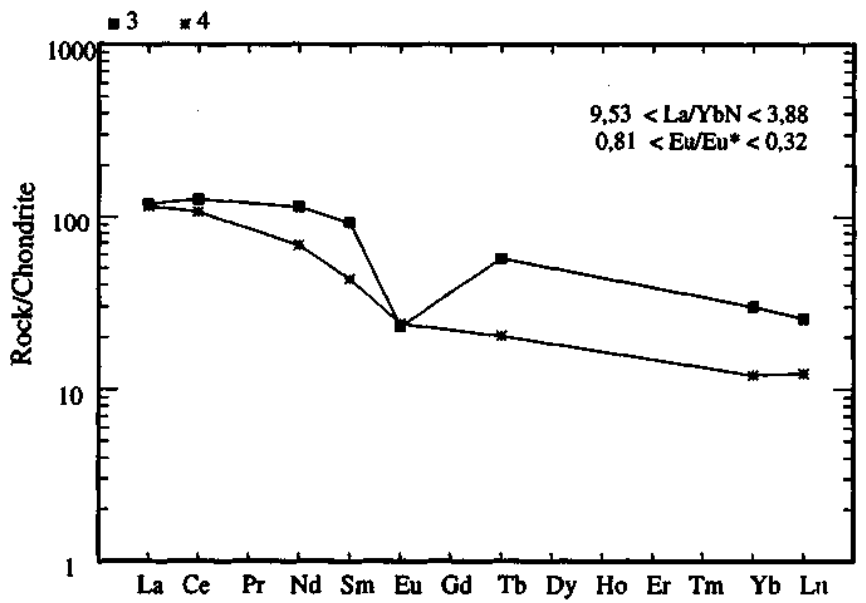

Figure 9 - Chondrite-normalized (Boynton 1984) rare earth elements (REE) distribution patterns for the intermediate terms of high-K calc-alkaline suite, Quirino Unit. Figura 9 - Padrões de distribuição de elementos de Terras Raras (ETR), normalizados para condrito (Boynton 1984), para os termos intermediários da suíte cálcio-alcalina de médio a alto-K da Unidade Quirino.

zircon crystals of several types from a sample of biotite granitic gneiss collected near Bom Sucesso village (sample 1, Fig.lb), Southern Paraiba Domain; and from zircon crystals of several types from a sample of homogeneous hornblende gneiss (Conceição quarry near Valença, State of Rio de Janeiro, sample 2, Fig. 1b), Northern Paraíba Domain. The last one yields $\mathrm{U}-\mathrm{Pb}$ zircon minimum ages of $2846 \mathrm{Ma}$ and 2981 Ma (Valladares 1996, Machado et al. 1996). The lower intercepts in concordia diagrams yield ages of $605 \pm 3 \mathrm{Ma}$ and $571 \pm 3 \mathrm{Ma}$, respectively. Dark sphene grains from the biotite gneiss yielded maximum growth ages of $577 \pm 1$ Ma. Sphene from leucossomes in mafic rocks of the Quirino Unit indicates partial fusion at $584 \pm 2 \mathrm{Ma}$. Younger ages are obtained on sphenes from the hornblende gneiss $(535 \pm 2 \mathrm{Ma})$, from

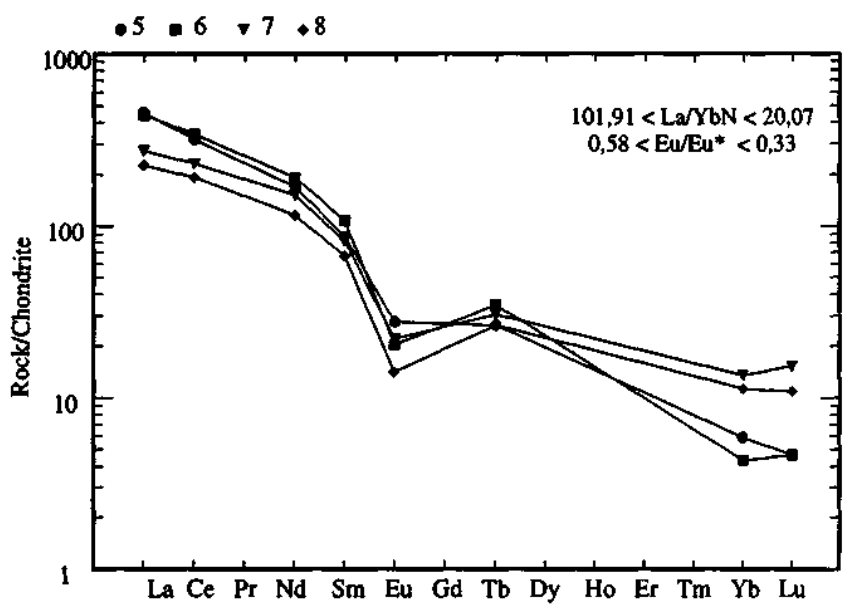

Figure 10 - Chondrite-normalized (Boynton 1984) rare earth elements (REE) distribution patterns for the acidic terms of high-K calc-alkaline suite, silica between 66-68\%. Figura 10 - Padrões de distribute de elementos de Terras Raras (ETR), normalizados para condrito (Boynton 1984), para os termos ácidos com sílica entre $66-68 \%$ da suíte cálcio-alcalina de médio a alto-K.

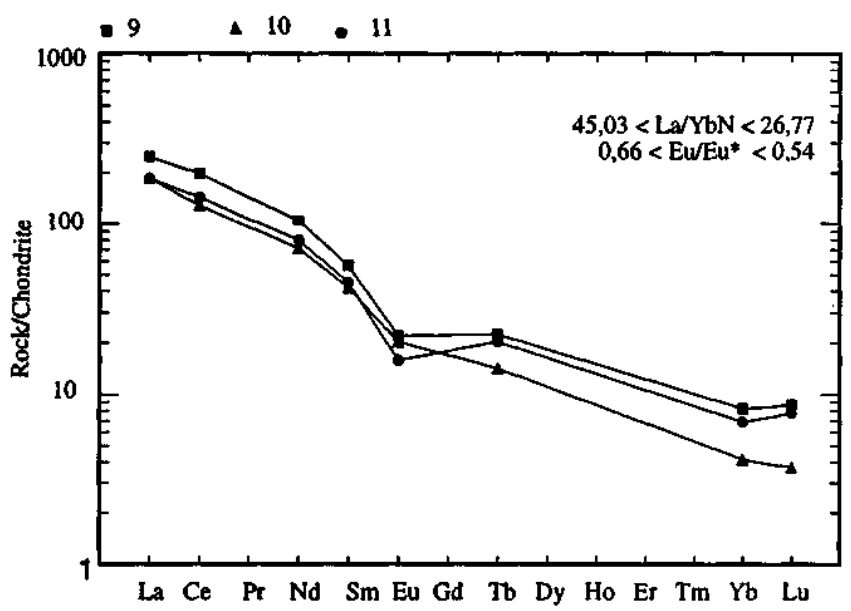

Figure 11 - Chondrite-normalized (Boynton 1984) rare earth elements (REE) distribution patterns for the acidic terms of high-K calc-alkaline suite, silica between $68-72 \%$. Figura 11 - Padrões de distribuição de elementos de Terras Raras (ETR), normalizados para condrito (Boynton 1984), para os termos ácidos com sílica entre $68-72 \%$ da suíte cálcio-alcalina de médio a alto-K.

biotite gneiss leucossome ( $530 \pm 4 \mathrm{Ma})$, and from hornblende gneiss leucocratic band ( $521 \pm 9 \mathrm{Ma})$. The youngest age $(503 \pm 8 \mathrm{Ma})$ was obtained on sphene from biotite gneiss. Detailed discussion on U-Pb gechronology of Paraíba do Sul Domain can be obtained in Valladares (1996) and Machado et al. (1996).

CONCLUSIONS The Quirino Unit yields U-Pb paleoproterozoic zircon ages of $2185 \pm 3 \mathrm{Ma}$ and $2169 \pm 3 \mathrm{Ma}$, obtained from the Southern and Northern Paraíba sub-domains, respectively, chronologically related to the Transamazonian event. Minimum ages of $2846 \mathrm{Ma}$ and $2981 \mathrm{Ma}$ reveal the pre-existence of Archean crust as $\mathrm{Pb}$ source of part of the investigated gneisses. These data suggest that the Quirino Unit could represent the basement of the supracrustal rocks of 


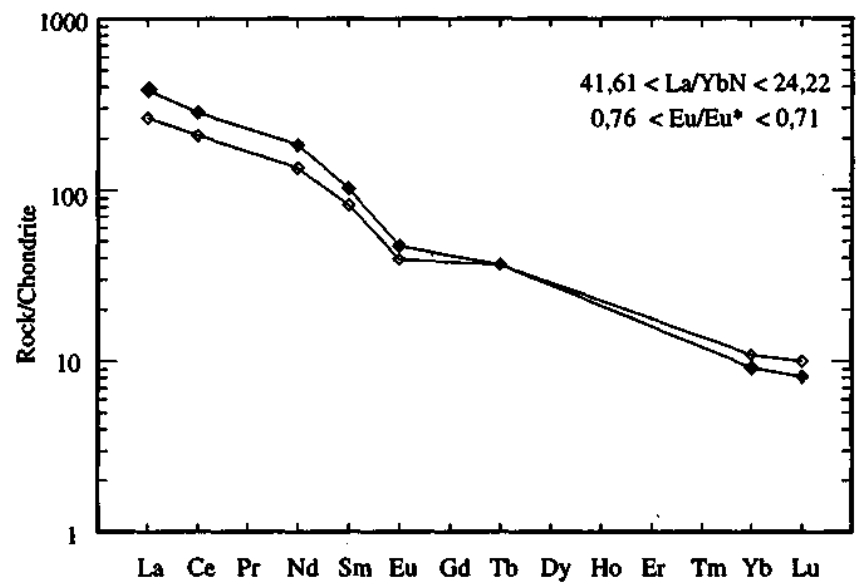

Figure 12- Chondrite-normalized (Boynton 1984) rare earth elements (REE) distribution patterns for the melanossomes of the orthogneisses of high-K calc-alkaline suite. Figura 12- Padrões de distribuição de elementos de Terras Raras (ETR), normalizados para condrito (Boynton 1984), para os melanossomas dos ortognaisses da suíte cálcio-alcalina de médio a alto-K.

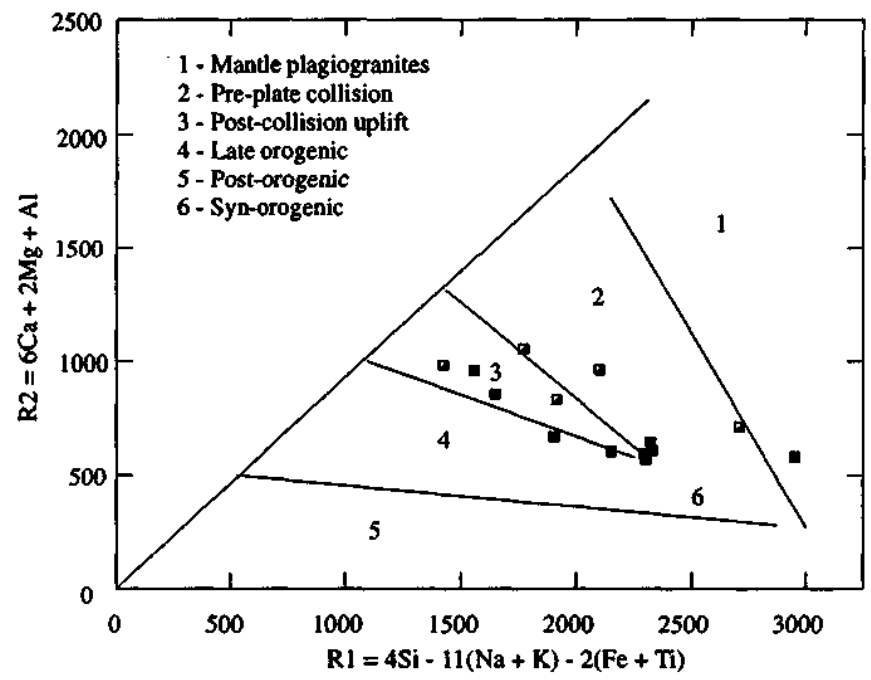

Figure 13- R1-R2 discriminant diagram, based on modern granitoids (Batchelor \& Bowden 1985), for the orthogneisses of Quirino Unit. Same symbols as in Fig 3. Figura 13- Diagrama discriminante R1-R2, baseado em granitóides modernos (Batchelor \& Bowden 1985), para os ortognaisses da Unidade Quirino. Mesmos símbolos que os da figura 3.

Paraíba do Sul Complex. Geochemical studies of the Quirino orthogneisses at the Southern Paraiba sub-domain discriminate two calc-alkaline suites: one of medium to high- $\mathrm{K}$ and other of high-K, enriched in LILE. Both suites may have been generated during the same Transamazonian collision, representing volcanic arc granites. Ages between 605-503 Ma indicate reworking of Quirino Unit rocks during the Brazilian Orogeny.

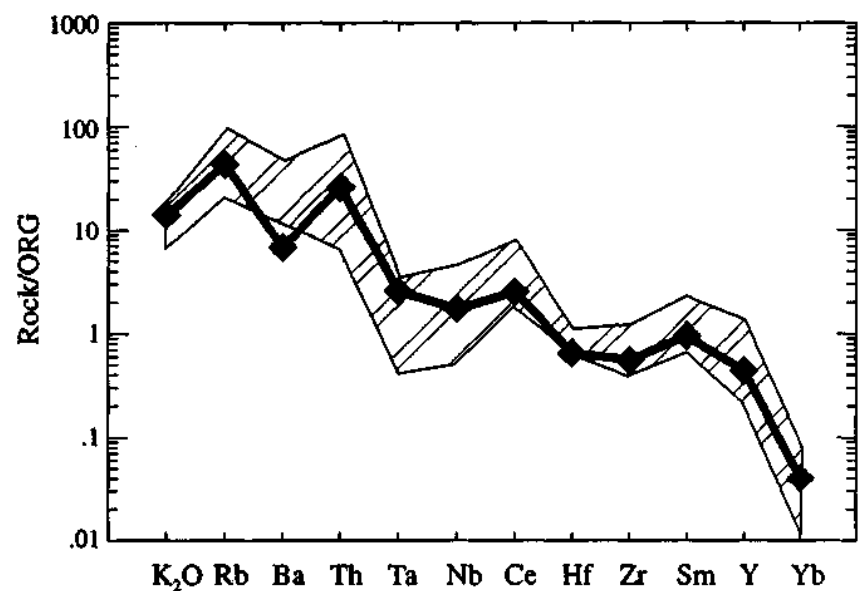

Figure 14- Envelope of multi-element patterns for the high-K calc-alkaline suite, normalized to Pearce et al. (1984) ORG values, with plote of volcanic arc granite from Chile. Figura 14- Diagrama de multi-elementos da sufte cálcio-alcalina de alto-K, normalizados para 0 granito de cadeia oceânica $(\mathrm{ORG})$, definido por Pearce et al. (1984), com plote do granito de arco vulcânico do Chile.

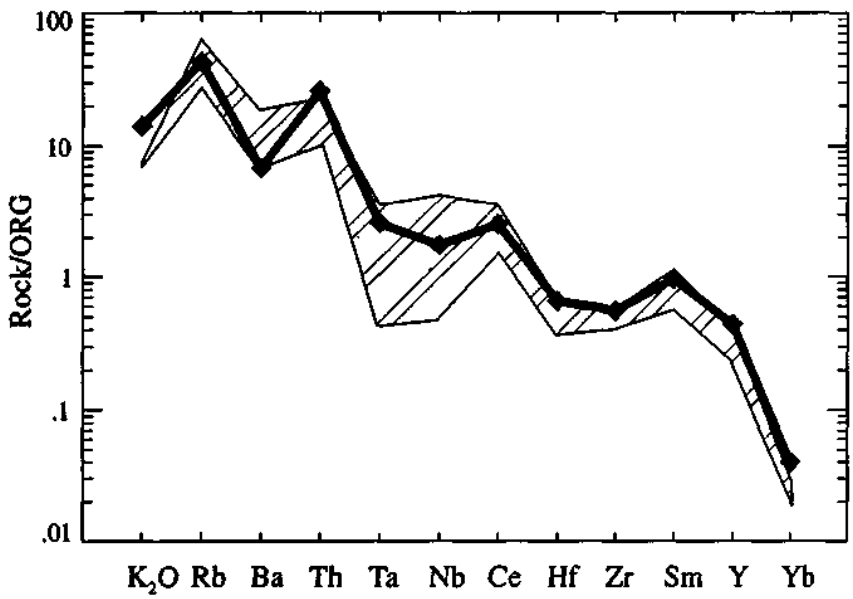

Figure 15- Envelope of multi-element patterns for the medium to high-K calc-alkaline suite, normalized to Pearce et al. (1984) ORG values, with plote of volcanic arc granite from Chile.

Figura 15 - Diagrama de multi-elementos da suíte cálcio-alcalina de médio a alto-K, normalizados para o granito de cadeia oceânica (ORG), definido por Pearce et al. (1984), com plote do granito de arco vulcânico do Chile.

Acknowledgements Field work was financed by $\mathrm{CNPq}$ through research scholarship to C.V. and research grant (Proc. 521577/93-4). The geochemical analyses were financed by FAPESP Proc. Geociencias/USP 92/0305-8. $\mathrm{U}-\mathrm{Pb}$ geochronogical analyses were carried out at GEOTOPUQAM, Canada. C.V. benefitted from a CAPES grant supporting her stay at UQAM. We're very grateful tkanked for N. Machado for his advice during this period.

\section{REFERENCES}

ALMEIDA, F.F.M. de. 1977.0 Cráton de São Francisco. Rev. Bras. Geoc.,, 7: 349-364.

ALMEIDA, F.F.M. de; HASUI, Y.; CARNEIRO, C.D.R. 1975. Lineamento de Além Paraíba. An. Acad. Bras. Ciênc., 47(3/4): 575.
ARTH, J.G.; BARKER, F.; PETERMAN, Z.E.; FRIEDMAN, 1.1978. Geochemistry of gabro-diorite-tonalite-trondhiernite suite of southwest Finland nad its implication for the origin of tonalitic and trondhjemitic magmas. J Petrol., 19: 289-316. 
BATCHELOR, R.A. \& BOWDEN, P. 1985. Petrogenetic interpretation of granitoid rocks series using multicationic parameters. Chem. Geol, 48: 43-55.

BOYNTON, W.R. 1984. Cosmochemistry of the rare earth elements meteorite studies. In: HENDERSON, P. ed. Rare Earth Element Geochemistry. Elsevier, Amsterdan. p. 63-114.

CAMPANHA, G.A.C. \& FERRARI, A.L. 1984. Lineamento Além Paraíba: um exemplo de zona de cisalhamento. In: CONGRESSO BRASILEIRO DE GEOLOGIA, 33, Rio de Janeiro, 1984. Anais...SBG, 12:5425-5432

CAMPOS NETO, M.C. 1992. A poção ocidental da Faixa Alto Rio Grande - Ensaio de Evolução Tectônica. São Paulo, 210p. (Tese de Doutoramento, Institute de Geociências da Universidade de São Paulo)

CASTRO, H.O.; ROCHA, R.L.S.; SPERLING, E.U.; BALTAZAR, O.F. 1984. Geologia das Folhas Mangaratiba, Ilha Grande, Cunhambembe Angra dos Reis, Rio Manbucaba, Campos de Cunha, Parati, Cunha, Picinguabae Juatinga. In: CONGRESSO BRASILEIRO DE GEOLOGIA, 33, Rio de Janeiro, 1984. Anais... Rio de Janeiro, SBG., v. 5, p. 2355-2367.

CORD AMI, U.G.; DELHAL, J.; LEDENT, 0.1973. Orogeneses superposed dans le Precambrien du Bresil sud-oriental (Etats du Rio de Janeiro et de Minas Gerais). Rev. Bras. Geoc., 3(1): 1-22

CORFU, f. \& STOTT, G.M. 1986. U-Pb ages for late magmatism and regional deformation in the Shebandowan Belt, Superior Province, Canada. Can. J. Earth Sci. 23: 1075-1082.

CONDIE, K.C.; ALLEN, P.; NARAYAMA, B.L. 1982. Geochemistry of the Archean low- to high-grade transition zone, Southern India. Contrib. Mineral. Petrol., 81: 157-167.

DAVIS, D.W. 1982. Optimum linear regression and error estimation applied to U-Pb data. Can. J. Earth Sci., 19: 2141-2149.

FIGUEIREDO, M.C.H \& CAMPOS NETO, MC. 1993. Geochemistry of the Rio Doce Magmatic Arc, Southeastern Brazil. An. Acad. Bras.Cienc., 65 (supl. 1): 63-81.

IRVINE, T.N. \& BARAGAR, W.R.A. 1971. A guide to the chemical classification of the common volcanic rocks. Can. J. Earth Sci., 8 523-548.

HASUI, Y. \& OLIVEIRA, M.A.F. 1984. A Província Mantiqueira: Setor Central. In: ALMEIDA \& HASUI. O Precambriano do Brasil. Edgard Blucher, 344p.

HEILBRON, M. 1993. Evolucão tectono-metamárfica da seção Bom Jardim de Minas-MG - Barra do Piraí-RJ, setor central da Faixa Ribeira São Paulo. 268p. (Tese de Doutoramento, Institute de Geociências da Universidade de São Paulo).

HEILBRON, M. 1995. O Segmento Central da Faixa Ribeira: Síntese Geologica e Ensaio de Evolução Geotectônica. Rio de Janeiro. 140 p. (Tese de Livre Docência, Faculdade de Geologia da Universidade do Estado do Rio de Janeiro).

HEILBRON, M.; VALERIANO, CM.; ALMEIDA, J.C.H \& TUPINAMBA, M.. 1991. A Megassinforma do Rio Paraíba do Sul e sua implicacão na compartimentacao tectônica do setor central da Faixa Ribeira. In: SIMPOSIO DE GEOLOGIA DO SUDESTE, 2, São Paulo, 1991. Atas...São Paulo, SBG:SP, p. 519-527.

KROGH, T.E. 1973. A low contamination method for hydrothermal decomposition of zircon and extraction of $\mathrm{U}$ and $\mathrm{Pb}$ for isotopic age determinations. Geochim. Cosmochim. Acta, 37: 485-494.

KROGH, T.E. 1982. Improved accuracy of U-Pb zircon ages by the creation of more concordant systems using an air abrasion technique. Geochim. Cosmochim. Acta, 46: 637-649.
LE MAITRE, R.W. 1989. A Classification of Igneous Rocks and Glossary of Terms. Blakcwell, Oxford, 193 p.

MACHADO, N.; GOULET, N.; GARIEPY, C. 1989. U-Pb geochronology of reactivated Archean basement and of Hudsonian metamorphism in the northern Labrador Trough. Can. J. Earth Sci., 26: 1-15.

MACHADO, N; VALLADARES, C.S.; HEILBRON, M.; VALERIANO, CM. (1996) U-Pb geocronology of the central Ribeira Belt (Brazil) and implications for the evolution of the Brazilian Orogeny. Precambrian Res., 79: 347-367.

MACHADO, R. 1986. Evolução geológica do Complexo Paraíba do Sul na porção ocidental do Estado do Rio de Janeiro. In: CONGRESSO BRASILEIRO DE GEOLOGIA, 34, Goiânia, 1986. Anais... Goiânia, SBG., v. 2, p. 1088-1095.

MACHADO, R. \& DEMANGE, M. 1991. Contexto Tectônico e estrutural dos granitóides brasilianos do estado do Rio de Janeiro. In: SIMPOSIO NACIONAL DE ESTUDOS TECTONICOS, 3, Rio Claro, SP, 1991. Boletim de Resumos...SBG-UNESP, p. 64-65.

MANIAR, P.O. \& PICCOLI, P.M. 1989. Tectonic discrimination of granitoides. Geol. Soc. Am. Bull., 101: 635-643.

MARQUES, L.S. 1988. Caracterização geoquímica das rochas vulcánicas da Bacia do Paraná: implicates petrogenéticas. São Paulo. 175p. (Tese de Doutoramento, Instituto de Geociências da Universidade de São Paulo).

O'CONNOR, J.T. 1965. A classification of quartz-rich igneous rocks based on feldspar ratios. U.S. Geological Survey Professional Paper, 525-B: 79-84.

PEARCE, J.A.; HARRIS, N.B.W.; TIDLE, A.G. 1984. Trace element discrimination diagramas for the tectonic interpretation of granitic rocks. J. Petrol., 25 (4): 956-983.

ROSIER, G. F. 1957. A Geologia da Serra do Mar, entre os picas de Maria Comprida e do Desengano (Estado do Rio de Janeiro). Rio de Janeiro, DNPM, GGM, 58p. (Boletim 166).

TROUW, R.A.J.; RIBEIRO, A. \& PACIULLO, F.V.P. 1994. A Faixa Alto Rio Grande reinterpretada como zona de interferência entre a Faixa Brasília e a Faixa Ribeira. In: CONGRESSO BRASILEIRO DE GEOLOGIA, 38, Balneário de Camboriú, 1994. Boletim de Resumes Expandidos... SBG, v. 1, p. 234-235.

VALERIANO, CM.; SIMOES, L.S.A.; HEILBRON, M. 1993. Estruturação da porção meridional da Faixa Brasília, sudoeste de Minas Gerais: implicações sobre a definição do limite regional do Cráton São Fransisco. In: SIMPOSIO SOBRE O CRATON DE SAO FRANCISCO, 2, Salvador, 1993. Anais...SGE, p:275-276.

VALLADARES, C. S. 1996. Evolução geológica do Complexo Paraíba do Sul, no segmento central da Faixa Ribeira, com base em estudos de geoquímica e de geocronologia U-Pb. São Paulo. 147p. (Tese de Doutoramento, Instituto de Geociências da Universidade de São Paulo).

\author{
Manuscrito A885 \\ Recebido em 15 de novembro de 1996 \\ Revisao dos autores em' 15 de abril de 1997 \\ Revisao aceita em 15 de junho de 1997
}

